Energy Research Journal 1 (1): 47-50, 2010

ISSN 1949-0151

(C) 2010 Science Publications

\title{
Energy Option for Small Scale Cashew Nut Processing in India
}

\author{
${ }^{1}$ Atul Mohod, ${ }^{2}$ Sudhir Jain and ${ }^{1}$ A.G. Powar \\ ${ }^{1}$ Department of Renewable Energy Sources, \\ College of Agriculture Engineering and Technology, DBSKKV, Dapoli (MS), India \\ ${ }^{2}$ Department of Renewable Energy Sources, \\ College of Technology and Engineering, MPUAT, Udaipur, India
}

\begin{abstract}
Problem statement: Cashew (Anacardium Occidentale L.) is one of the important tropical crops. India processed about 11,80,000 metric tons of raw cashew nut seeds through 3650 cashew processing industries scattered in many states of country. The cashew nut processing industries are typically located in the rural and backward areas. The most significant difficulty in processing cashew nuts is that the hard outer shell, which contains the edible kernel, contains a caustic oil which can burn the skin and produce noxious fumes when heated. More recently, smaller scale factories use the steaming and cutting method. Approach: At present cashew industries facing problem of interrupted power supply which affect the economical growth of the sector. The cashew industries in India employed different unit operations/methodology for processing depend on variety of raw material, location, technological mechanization, availability of secured energy supply. Results: Large disparities in energy intensity for similar process in the cashew processing reveal the scope for energy conservation to be in the order of $30-48 \%$. There is good scope for effective utilization of solar energy and biomass gasification technology for energy generation in the sector. Conclusion: This study deled with the elucidation of the processing operations in the small-scale cashew processing of Maharashtra with identification of energy consumption for unit operations. The energy conservation opportunities in the cashew nut processing sector were discussed in the study. The scope for utilization of renewable energy technologies like solar dryers for drying of cashew nut seed and cashew kernel were elaborated. The characterization of cashew shell waste available in the processing industry revealed the scope for thermal gasification of shell for heat generation.
\end{abstract}

Key words: Cashew mills, processing, energy, saving

\section{INTRODUCTION}

India is the largest producer and processor of cashews (Anacardium occidentale L.) in the world. Total area in India under cashew cultivation is about $8,54,000$ ha with annual production of $6,20,000$ tons giving average productivity $820 \mathrm{~kg} \mathrm{~h}^{-1}$ with highest productivity reported in Maharashtra $\left(1500 \mathrm{~kg} \mathrm{ha}^{-1}\right)$ from 1,64,000 ha land under cultivation and produced 1, 97, 000 tons of raw cashew nut seeds. India processed about 11,80,000 tones of raw cashew nut seeds through 3650 cashew processing mills scattered in many states of country which increased rapidly from 170 in 1959 to over 3650 in year 2008 provide employment to over 0.5 million people of, which 95\% are women (Anonymous, 2009).

Maharashtra state has total 2200 cashew processing units out of which 1850 are small cottage mills which processed about 20, 0000 metric tons of raw cashew nut per annum mainly located in Konkan region (7017$74^{\circ} 31^{\prime} \mathrm{E}$ Longitude and $1537-20^{\circ} 20^{\prime} \mathrm{N}$ Latitude) of Maharashtra comprising five districts namely Mumbai, Thane, Raigadh, Ratnagiri and Sindhudurg with 1, 31, 288 ha land area under cultivation producing 1, 92, 600 tons of raw cashew per annum (Epitom, 2009).

A wide disparity in energy consumption to produce the same quantity of similar products in cashew processing was observed (Balasubramanian, 2007). The wide variations in energy intensity of these cashew mills reveal the scope for energy conservation to be in the order of $30-48 \%$. The wide variations in energy intensity of these mills due to variety of the fuel, installed capacity, production and percent utilization of the capacity reveals the scope for energy conservation. These operations need to study for efficient end use efficiency (Ramachandra, 1998). The

Corresponding Author: Atul Mohod, Department of Renewable Energy Sources,

College of Agriculture Engineering and Technology, DBSKKV, Dapoli (MS), India 
main purpose of energy use assessment is to judge energy use pattern, energy loss sources and excess energy use points (Kulkarni, 2000).

\section{MATERIALS AND METHODS}

The different unit operations involved in smallscale cashew nut processing mill in the context of Konkan region of Maharashtra (7017-74'31'E Longitude $1537-20^{\circ} 20^{\prime} \mathrm{N}$ Latitude) was elucidated by conducting the randomized sample survey of registered 122 small scale cashew processing mills in the region. The survey of small-scale cashew processing mills covered the general information, background information, process and product details and important factors that affect the data collection. The survey covered the unit operations performed, level and pattern of energy consumption and technologies in use for cashew nut processing (Kulkarni, 2000; Ramachandra, 1998). The different form of energy use for the unit operations in the small-scale cashew nut processing mill was observed along with the time of operation. The opportunity for the conservation of energy and suitable commercial viable renewable energy technologies to perform the unit operations in small scale cashew nut processing was identified based on the type of energy, present mode of energy utilization, technological advancement and availability of secure power source.

The quantity of cashew shell waste generated in the small scale processing mill was estimated by noting the input raw material and output material in term of finished product and by product. The waste cashew shell was estimated in term of $\mathrm{kg} 1000 \mathrm{~kg}^{-1}$ of raw cashew nut seeds. The proximate analysis (fraction of mass of moisture, volatile, ash and fixed carbon) of a sample of cashew shell was carried out using the standard analytical procedures. The proximate analysis of cashew shell waste was carried out using the analytical method ASTM-D-3173-3175. The analysis of moisture was determined by the method of drying oven (ASTM D-3173). The quantity of ash was determined according to ASTM D-3174. The fraction of volatile was determined according to ASTM D-3175. The fixed carbon was determined by difference. The higher heating value of solid fuels was determined by experiment of bomb calorimeter (ASTME-711) where the combustion was carried out in environment with high pressure of oxygen (to ensure complete combustion) saturated with steam of water (to ensure that all the water was formed in liquid).

\section{RESULTS AND DISCUSSION}

The results obtained from the randomized sample survey of the small scale cashew nut processing were discussed as below.

Elucidation of unit operations in small scale cashew nut processing: The small scale cashew nut processing mills in the region employed different unit operations/ methodology for processing of cashew nut. The general process flow chart for cashew processing adopted in the study area for cashew nut processing is described as follows and shown in Fig. 1.

Sun drying of raw cashew nut seed: The raw nuts after harvest are sun dried for 2-3 days to reduce the moisture from $25-7-8 \%$ (wb) and stored in gunny bag. The well-dried seeds are stored in the $80 \mathrm{~kg}$ capacity gunny bags for further processing.

Steaming of raw cashew nut seed: This method now a day adopted widely all over the surveyed region. The raw nuts are steamed conditioned at about $4.5-5 \mathrm{~kg} \mathrm{~cm}^{-2}$ pressure for 25-30 min and then allowed for 18-24 h cooling at room temperature. A cylindrical steam cooker with provision of cashew nut feeding at the top and discharging of cooked nuts from the side near bottom, has a capacity of holding $15-60 \mathrm{~kg}$ of cashew nut in a batch.

Cooling of steamed cashew nut seed: The cooling and tampering of the steamed nuts is carried out $18-24 \mathrm{~h}$ in the shed to bring the steamed nut in equilibrium with the atmospheric conditions.

Cutting and separation: Raw nuts after steaming and cooling are shelled to remove kernels with the help of hand cum pedal operated shell cutter. The separation of cashew kernel from the cut steamed nuts is carried out manually by using the sharp knife. This unit operation produced the cashew shell as by-product, further used as feedstock for the cashew nut shell liquid extraction.

Drying of cashew kernels: The kernel coming from the cutting and separation section contains a brown cover, known as 'test', over it. To remove test over the kernel and also control the moisture content in the kernels, they are exposed to prolonged and controlled heating with hot air at $65-70^{\circ}$ centigrade in perforated tray for $6-8 \mathrm{~h}$. About $5-8 \%$ of moisture was removed from the kernels in the process. 
Energy Rec. J. 1 (1): 47-50, 2010

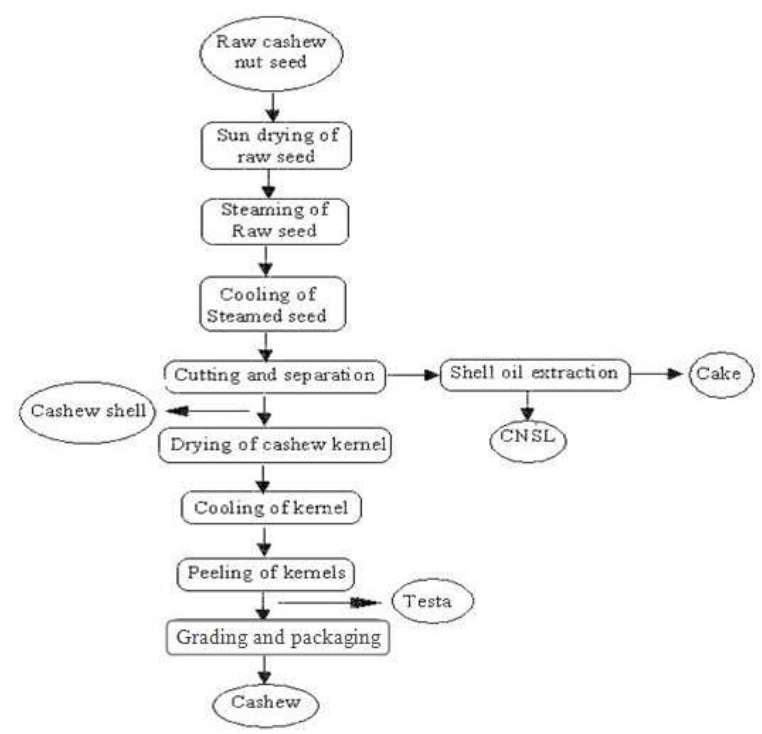

Fig. 1: Flow chart of cashew nut processing in small scale processing mills

Cooling of cashew kernels: The cooling of hot cashew kernels from the drying operation is carried out in the shed to bring down the temperature of the kernels.

Peeling of cashew kernels: The brown tested over the kernel was peeled off manually by using the sharp knife. The women workers in the mill generally performed this operation.

Grading and packaging: The kernels are graded manually by hand/sieve Cashew Export and Promotion Council, India (CEPC) specifications were adopted for grading of cashew kernels.

The randomized sample survey of 122 small scale cashew nut processing mills revealed that, the small scale cashew nut mills in Konkan region of Maharashtra (India) widely followed steam roasting process due to better control over the process which retain the valuable Cashew Nut Shell Liquid (CNSL) in the shell as well as generate the huge quantity of shell for further utilization as a fuel. The average working day of the mills is about 227 days in the year depending on the rainy season and availability of raw cashew nut seeds. The average installed production capacity of the surveyed mills is about $9800 \mathrm{~kg}$ of raw cashew nut seeds per annum. The actual raw material processed by these mills is in the tune of $5833 \mathrm{~kg}$, which revealed the average percent plant capacity utilization of $55 \%$ only. The women workers are prominent in the small-scale cashew nut processing mills.
Table 1: Unit operations and type of energy for cashew nut processing

\begin{tabular}{|c|c|c|c|c|c|}
\hline \multirow[b]{2}{*}{ Unit operation } & \multirow[b]{2}{*}{ Time (h) } & \multicolumn{4}{|c|}{ Type of energy use } \\
\hline & & Electrical & Thermal & Manual & Solar \\
\hline $\begin{array}{l}\text { Drying of raw } \\
\text { cashew nut }\end{array}$ & $16-24$ & - & - & - & + \\
\hline $\begin{array}{l}\text { Steaming } \\
\text { of raw C.nut }\end{array}$ & 3-Feb & + & + & + & - \\
\hline $\begin{array}{l}\text { Cooling of } \\
\text { steamed C. nut }\end{array}$ & $18-24$ & & & + & \\
\hline $\begin{array}{l}\text { Cutting and } \\
\text { separation }\end{array}$ & 10-Aug & - & - & + & - \\
\hline $\begin{array}{l}\text { Drying of } \\
\text { cashew kernels }\end{array}$ & 7-Jun & + & - & + & - \\
\hline $\begin{array}{l}\text { Cooling of } \\
\text { kernels }\end{array}$ & 4-Mar & - & - & + & - \\
\hline $\begin{array}{l}\text { Peeling of } \\
\text { kernels }\end{array}$ & 7-Jun & - & - & + & - \\
\hline $\begin{array}{l}\text { Grading and } \\
\text { Packaging }\end{array}$ & $3-\mathrm{Feb}$ & - & - & + & - \\
\hline
\end{tabular}

The unit operations performed in the mills was semi automatic type using different machineries supplied by the registered manufacturer of Govt. of Maharashtra. Most of the small scale cashew nut processing mills used indirect type of baby boiler with cooker for steaming operation. The secure and constant electricity supply play an important role the processing as most of the kernel drying ovens are operated on the electricity for hot air generation.

Energy consumption and option in cashew nut processing: The unit operations performed to convert the raw cashew seed in to the cashew kernels with time requirement and type of energy use to perform the operation are summarized in Table 1.

It is observed that, the most energy and time intensive unit operations in cashew processing are drying of raw seed in open sun, steaming of raw nuts and cashew kernel drying. The alternative energy option through the renewable energy technologies could provide the sustainable development and secure supply of energy. Numerous renewable energy technologies are available technically and commercially for decentralized energy supply in the rural small-scale cashew nut processing industries.

Solar tunnel drying technology could be one of the viable option for reduction of commercial energy and process time for drying of agricultural products. The naturally available solar energy can effectively be utilized to meet out the drying needs of raw cashew nut normally requiring 2-3 days of drying in open sun to bring down the moisture content from $24-9 \%$. The conventional drying of cashew kernel to reduce the moisture content from $12-13 \%$ to below $4 \%$ at $60^{\circ} \mathrm{C}$ for $4-5 \mathrm{~h}$ with electrical energy is one of the energy intensive operations in cashew processing. 
Table 2: Proximate analysis and heating value of cashew nut shell

\begin{tabular}{ll}
\hline Property & Cashew nut shell \\
\hline Moisture content (\%) & 06.47 (ASTMD-3173) \\
Volatile matter (\%) & 72.00 (ASTMD-3175) \\
Ash content (\%) & 01.05 (ASTMD-3174) \\
Fixed carbon (\%) & 20.48 (by difference) \\
Higher heating value, $\mathrm{kcal} \mathrm{M}^{-3}$ & 4890.23 (ASTME711) \\
\hline
\end{tabular}

A forced convection indirect solar cabinet dryer could be viable option to provide the required heat for the drying of the kernel. This will provide the constant heat to the product as well retain its nutritional and organoleptic quality. The shelling of raw seed coat to remove the kernel generate shell waste which can be utilized as a source of energy for heat generation through gasification technology with better control and higher end use efficiency. The integration of these renewable technologies is the need of agro industry for better performance and sustainable development.

Analysis of cashew nut shell: The result obtained from the proximate analysis (fraction of mass of moisture, volatile, ash and fixed carbon) and heating value of cashew nut shell is summarized in Table 2.

The proximate analysis of cashew nut shell revealed the suitability of the fuel for gasification. It is observed that, the average moisture content of cashew nut shell waste is $6.47 \%$. The moisture content of the fuels under study is in the acceptable limit (below 15\%) to ensure free flow and good quality gas production. The average of volatile matter content in cashew nut shell is $72 \%$. The higher amount of volatile matter revealed the suitability of the fuel for gasification. Also the data indicated that, the average ash content of the cashew nut shell is $1.05 \%$, which revealed their suitability for the gasification with minimum blocking of flow of air and fuel, formation of clinkers. The most desirable component, which governed the suitability of the fuel for gasification, that the average fixed carbon is $20.48 \%$ in cashew nut shell. The heating value of fuel is the major factor determining the suitability of fuel for gasification. The results obtained showed that the average higher heating value of the cashew nut shell is $4890.23 \mathrm{Kcal} \mathrm{Kg}^{-1}$.

\section{CONCLUSION}

The study revealed that, three identified energy intensive operations in cashew nut processing are cashew nut drying, cashew nut steaming and drying of cashew kernels, altogether accounting maximum energy and time for the processing. The elucidation and type of energy consumption for unit-processing operations reveled the scope for energy conservation and utilization of renewable energy based technologies like solar tunnel dryer and forced convection solar cabinet dryer. The fuel analysis of cashew nut shell revealed the scope for its utilization through gasification technology for the generation of process heat.

\section{REFERENCES}

Anonymous, 2009. Cashew production technology. Technical Note, National Research Center for Cashew, (ICAR), Puttur, Karnataka, pp: 12-34.

Balasubramanian, D., 2007. Optimization of processing parameters using farm level cashew nut processing. J. Agric. Eng. Today, 32: 35-41.

Epitom, 2009. District wise agricultural data base for Maharashtra; 1961-2008. EPW Res. Found., 2: 11-14.

Kulkarni, S.D., 2000. Energy use assessment in agro processing operations: Factors to be considered for data collection for comparison. J. Agric. Eng. Today, 24: 51-61.

Ramachandra, T.V., 1998. Energy utilization in rural mills in Karnataka. Int. J. Ambient Energy, 19: 75-92. http://cat.inist.fr/?aModele $=$ afficheN\&cpsidt $=2321$ 700 